JURNAL SEHAT MASADA VOLUME XIII NOMOR $2 \quad$ Juli $2019 \quad$ ISSN : 1979-2344

\title{
PERBEDAAN KUALITAS HIDUP PADA PASIEN RETINOPATI DIABETIK NON-PROLIFERATIF BERAT DAN RETINOPATI DIABETIK PROLIFERATIF DI POLIKLINIK VITREORETINA INSTALASI RAWAT JALAN PUSAT MATA NASIONAL RUMAH SAKIT MATA CICENDO BANDUNG
}

\author{
Melan Nurhayati, S.Kep ${ }^{1)}$, Irma Nur Amalia, S.Kep.,Ners.,M.Kep ${ }^{2)}$., Hafsa.,M.Kep ${ }^{3)}$ \\ ${ }^{1)}$ Pusat Mata Nasional RS mata Cicendo ${ }^{, 2)}$ Program Studi Sarjana Keperawatan STIKes Dharma Husada \\ ,3), RSUP Dr. Hasan sadikin Bandung \\ 1) mysoul.80@gmail.com \\ ${ }^{2)}$ irma.nuramalia@yahoo.com \\ ${ }^{3)}$ hf_andisa@yahoo.com
}

\begin{abstract}
Diabetic retinopathy $(R D)$ is a specific microvascular complication of Diabetes Mellitus (DM) that causes visual impairement. Visual impairment that occurs in DR patients can affect the quality of life related to eye health. The latest data about DR patients from National Eye Center (NEC) Cicendo Eye Hospital Bandung was 2035 patients with Severe Non-proliferative Diabetic Retinopathy (Severe NPDR) and Proliferative Diabetic Retinopathy (PDR) are the most happened. The purpose of this study was to determine quality of life differences in patients with severe NPDR and PDR at the Vitreoretina Polyclinic Outpatient Departement NEC Cicendo Eye Hospital Bandung. This Research is a quantitative non-experimental with a comparative descriptive design. The sample was divided into two groups, they are Severe NPDR and PDR group, with 30 respondents each. The instrument that used in this study is the National Eye Institute Visual Function Questionaire-25 (NEI VFQ-25). Data analized by Chi Square test. The results showed that no differences in qualityof life in patients with severe NPDR and PDR in the Vitreoretina Polyclinic Outpatient Departement NEC Cicendo Eye Hospital Bandung $(p=1,000)$. This study illustrates the importance of providing education and encouragement to the patients with Severe NPDR and PDR for regular control about their visual impairment and their diabetes, so the patients will spared from decressing in their quality of life.
\end{abstract}

Keywords : Non-proliferative Diabetic Retinopathy, Proliferative Diabetic Retinopathy, Quality of Life

\begin{abstract}
ABSTRAK
Retinopati Diabetik (RD) merupakan komplikasi mikrovaskular spesifik dari DM yang mengakibatkan gangguan pada mata. Gangguan penglihatan yang terjadi pada pasien RD dapat mempengaruhi kondisi kualitas hidup terkait kesehatan mata. Data terbaru pasien RD tahun 2012-2015 Pusat Mata Nasional Rumah Sakit Mata Cicendo Bandung yaitu 2035 pasien, dengan pasien Retinopati Diabetik Nonproliferatif Berat (RDNP Berat) dan Retinopati Diabetik Proliferatif (RDP) paling banyak terjadi. Tujuan penelitian ini yaitu untuk mengetahui perbedaan kualitas hidup pada pasien RDNP Berat dan RDP di Poliklinik Vitreoretina Instalasi Rawat Jalan PMN RS Mata Cicendo Bandung.Penelitian merupakan kuantitatif non-eksperimental dengan desain descriptive comparative.Sampel dibagi dua kelompok, yaitu kelompok RDNP berat dan RDP, dengan masing-masing 30 responden. Instrumen yang digunakan yaitu National Eye InstituteVisual Function Questionaire-25 (NEI VFQ-25). Analisis data menggunakan uji Chi Square. Hasil penelitian menunjukkan tidak ada perbedaan kualitas hidup pada pasien retinopati diabetik non-proliferatif berat dan retinopati diabetik proliferatif di Poliklinik Vitreoretina Instalasi Rawat Jalan PMN RS Mata Cicendo Bandung $(\mathrm{p}=1,000)$. Penelitian ini Jurnal Penelitian Kesehatan STIKes Dharma Husada Bandung 
menggambarkan pentingnya memberikan edukasi dan dorongan kepada pasienRDNP Berat dan RDP untuk kontrol secara teratur baik mengenai gangguan penglihatannya maupun penyakit diabetesnya, sehingga pasien terhindar dari kondisi penurunan kualitas hidup yang lebih buruk.

Kata kunci : Retinopati Diabetik Non-proliferatif Berat, Retinopati Diabetik Proliferatif, Kualitas Hidup

\section{PENDAHULUAN}

Retinopati Diabetik (RD) merupakan komplikasi mikrovaskular spesifik dari DM dan mempengaruhi 1 dari 3 orang dengan DM (ICO 2017). RD terjadi sebagai akibat langsung dari hiperglikemia kronis yang menyebabkan kerusakan kapiler retina sehingga menimbulkan kebocoran kapiler dan penyumbatan kapiler (Chen et al., 2010 dalam Cavan et al., 2017; IDF dan The Fred Hollows Foundation, 2015).

ICO (2017), mengklasifikasikan RD menjadi dua stadium, yaitu RDNP dan RDP. RDNP dibagi menjadi 3 stadium yaitu RDNP ringan, RDNP sedang, dan RDNP berat.

RDNP merupakan fase awal dari $\mathrm{RD}$, pada fase ini terjadi kerusakan mikrovaskuler pada retina yang ditandai dengan kerusakan pada pembuluh darah kecil yang memasok retina sehingga mengakibatkan kebocoran atau penyumbatan pembuluh darah retina (International Federation on Ageing/IFA, International Agency for the Prevention of Blindness/IAPB\& IDF, 2016). Kerusakan yang terjadi pada stadium awal ini, dapat menimbulkan sedikit gejala ringan pada pasien atau bahkan sering tidak menimbulkan gejala sama sekali, sehingga pasien sering tidak menyadarinya (IDF dan The Fred Hollows

Foundation, 2015).

$\mathrm{RD}$ dengan stadium lanjut dapat menimbulkan gejala yang meliputi floaters, yaitu penglihatan seperti melihat jaring labalaba dan bintik-bintik yang beterbangan (Bhavsar, 2017; American Academy of Ophthalmology, 2016; IDF dan The Fred Hollows Foundation, 2015). RDNP berat dan RDP yang merupakan stadium RD lebih lanjut dapat menimbulkan gangguan penglihatan dan dapat mengakibatkan kesulitan dalam memenuhi aktifitas sehari-hari (Stewart, 2017; IDF dan The Fred Hollows Foundation, 2015).

Brown (1999) dalam Alinia et al. (2017) mengatakan bahwa gangguanpenglihatan yang terjadi pada pasien RD dapat mempengaruhi kondisi kualitas hidup terkait dengan kesehatan mata. Kualitas hidup yang berhubungan dengan kesehatan didefinisikan oleh Wenger dan Furberg dalam Yousefi et al. (2016) sebagai karakteristik yang berharga bagi pasien dan merupakan hasil dari perasaan yang diinginkan dan nyaman terkait dengan peningkatan fisik, emosi dan kinerja logis.

Berbagai instrumen untuk mengukur kualitas hidup pada pasien dengan gangguan penglihatan telah banyak dikembangkan. Menurut Milne et al. (2012) instrumen paling umum yang digunakan untuk mengukur kualitas hidup pada pasien RD adalah National 
Eye Institute Visual Function Questionnaire25(NEI VFQ-25).

Instrumen NEI VFQ-25 dikelompokkan ke dalam dalam 12 sub-skala penilaian yang meliputi: kesehatan umum, penglihatan umum, nyeri pada mata, aktivitas dengan penglihatan dekat, aktivitas dengan penglihatan jauh, fungsi sosial, kesehatan mental, kesulitan berperan dalam masyarakat, ketergantungan, berkendaraan, penglihatan warna, penglihatan perifer.

Penelitian yang dilakukan Pereira et al. (2017) tentang kualitas hidup menggunakan instrumen NEI VFQ-25 menyebutkan bahwa kualitas hidup secara signifikan lebih rendah pada pasien $\mathrm{RD}$ dibandingkan dengan yang tidak memiliki RD. Sementara pasien dengan RD yang parah dilaporkan memiliki kualitas hidup yang lebih buruk dibandingkan dengan $\mathrm{RD}$ yang masih ringan (International Council Of Ophthalmology, 2017; Pereira et al., 2017). Manaviat et al. (2016) yang juga menggunakan instrument NEI VFQ-25 dalam penelitiannya mengenai hubungan $\mathrm{RD}$ dan tingkat keparahannya dengan kualitas hidup menemukan bahwa kualitas hidup menurun seiring dengan tingkat keparahan $\mathrm{RD}$ yang meningkat.

Dampak yang paling signifikan pada pasien RD yaitu kegiatan sehari-hari yang berhubungan dengan penglihatan, ketergantungan dan kesehatan mental (Pereira et al, 2017; Manaviat et al, 2016). Selain itu kehadiran $\mathrm{RD}$ juga menimbulkan penurunan yang signifikan pada komponen fisik (Davidov et al., 2009).
Studi pendahuluan dilakukan di Pusat Mata Nasional Rumah Sakit Mata Cicendo Bandung pada April-Juni 2019didapatkan data pasien dengan diagnosis RD sebanyak 1227 orang. Hasil wawancara peneliti kepada 10 pasien RD, 6 diantaranya mengatakan dalam kondisi kesehatan yang kurang bagus, sebagian besar alasan pasien yaitu akibat mengalami penurunan ketajaman penglihatan yang signifikan setelah mengalami RD. Enam pasien tersebut mengatakan aktivitas, seperti membaca, memasak, menyetir kendaraan, mengenal ekspresi wajah orang yang ada di hadapannya menjadi terganggu akibat penurunan ketajaman penglihatan tersebut. Pasien mengatakan penglihatannya menjadi seperti terhalang oleh jaring-jaring, penglihatan juga sering menjadi kabur secara hilang timbul, pasien merasa kesulitan beradaptasi di tempat dengan cahaya yang redup. Dua pasien mengatakan khawatir dengan kondisi kesehatan matanya sekarang, pasien takut menjadi buta total. Dua pasien lainnya mengatakan merasa malu dengan kondisinya sekarang, karena pasien tidak bisa beraktifitas secara normal, pasien mengatakan jadi ketergantungan kepada keluarga dan orang-orang di sekitarnya, dan dampaknya pasien jadi lebih sering berada di rumah dibandingkan beraktifitas dan bersosialisasi di luar rumahnya.

Pengukuran kualitas hidup yang berisi persepsi subyektif tentang penyakit dan dampaknya terhadap aktivitas kehidupan sehari-hari merupakan hal yang penting untuk memperkirakan beban penyakit, membuat 
rencana tindakan untuk mencegah atau mengendalikan penyakit dan untuk evaluasi mengenai intervensi terapeutik kepada pasien (Kamran, et al., 2017; Nickels et al., 2017).

Dengan dilakukan pengukuran kualitas hidup pada pasien, hubungan antara pasien dengan tenaga kesehatan akan meningkat dan dengan tindak lanjut dari hasil pengukuran kualitas hidup tersebut akan membantu kualitas hidup pada pasien meningkat pula (Kamran et al., 2017; Rapkin, 2004 dalam Wahyuni et al., 2014).

Perawat sebagai salah satu profesional kesehatan memiliki peran penting dalam mengelola dan mencegah komplikasi DM. Intervensi perawat dalam mencegah dan mengelola pasien DM meliputi pengaturan diet, pengaturan berat badan, olahraga, dan edukasi (The Royal College Ophthalmologist, 2012; Wahyuni et al., 2014). Tercapainya asuhan keperawatan yang komprehensif dalam mengelola dan mencegah terjadinya komplikasi diharapkan dapat meningkatkan kualitas hidup pasien (Wahyuni et al., 2014).

Berdasarkan fenomena dan data yang yang telah diuraikan di atas penulis tertarik melakukan penelitian tentang "Perbedaan Kualitas Hidup Pada Pasien Retinopati Diabetik Non-Proliferatif Berat dan Retinopati Diabetik Proliferatif Di Poliklinik Vitreoretina Instalasi Rawat Jalan Pusat Mata Nasional Rumah Sakit Mata Cicendo Bandung."

\section{METODE}

Penelitian ini merupakan kuantitatif noneksperimental dengan desain descriptive comparative. Sampel dibagi menjadi dua kelompok, yaitu kelompok RDNP berat dan RDP, dengan masing-masing 30 responden. Instrumen yang digunakan yaitu National Eye InstituteVisual Function Questionaire-25 (NEI VFQ-25).

Uji statistik yang digunakan adalah $C h i$ square dengan koreksi Yates. Hasil uji Chi square akan dipakai bila memenuhi syarat, yaitu sel yang memiliki nilai expected kurang dari lima maksimal $20 \%$ dari jumlah sel (Dahlan, 2014), bila syarat tidak terpenuhi peneliti akan menggunakan alternatif $\mathrm{Uji}$ Fisher.

\section{HASIL DAN PEMBAHASAN}

Tabel 4.1 menunjukkan bahwa distribusi jenis kelamin sebagian besar $(58,3 \%)$ adalah perempuan. Distribusi usia sebagian besar $(63,3 \%)$ termasuk kategori usia $>55$ tahun. Hampir separuhnya (46,7\%) merupakan responden dengan tingkat pendidikan SMA. Sebagian besar (65\%) responden tidak bekerja dan separuhnya (50\%) memiliki durasi DM 510 tahun.

Distribusi jenis kelamin pada penelitian ini sebagian besar $(58,3 \%)$ adalah perempuan. Hal ini sesuai dengan Billah et al (2016) dalam penelitiannya bahwa jumlah RD pada perempuan lebih dominan daripada laki-laki. Sedangkan hasil penelitian Ozawa et al. (2014), justru menyebutkan bahwa terdapat hubungan signifikan pada laki-laki untuk menderita retinopati tahap berat pada DM tipe 1, namun pada DM tipe 2 tidak menunjukkan hubungan yang signifikan.

Karakteristik responden dari kategori usia didapatkan sebagian besar $(63,3 \%)$ merupakan 90 
responden dengan kategori usia $>55$ tahun. Penelitian oleh Klein et al. (2010)menyatakan bahwa pada 996 penderita DM, sekitar 90\% dari pasien RD berusia lebih dari 50 tahun. Hal ini sejalan dengan penelitian Goyal et al. (2017), bahwa RD secara signifikan terkait dengan usia yang lebih tua. Namun dalam penelitian yang dilakukan Pan et al. (2017) ditemukan bahwa prevalensi RD menurun seiring dengan peningkatan usia.

Tingkat pendidikan dari total 60 responden, hampir separuhnya $(46,7)$ adalah tingkat SMA dan sebagian besar (65\%) dari responden tidak bekerja, dengan alasan berhenti bekerja/pensiun/tidak bekerja.
Menurut Boyd et al. (2010), tidak banyak penelitian yang membandingkan status sosial budaya dan RD, termasuk pendidikan dan pekerjaan.

Karakteristik responden berdasarkan durasi DM, didapatkan bahwa separuhnya (50\%) memiliki durasi DM 5-10 tahun. Menurut AAO (2016), durasi DM adalah faktor risiko utama yang terkait dengan perkembangan RD. Setelah 5 tahun, sekitar $25 \%$ pasien akan

mengalami retinopati, setelah 10 tahun, hampir $60 \%$ memiliki retinopati, dan setelah 15 tahun, $80 \%$ memiliki retinopati (AAO, 2016).

Tabel 1 Distribusi Frekuensi Gambaran Karakteristik Pasien RDNP Berat dan RDP di Poliklinik Vitreoretina Instalasi Rawat Jalan Pusat Mata Nasional Rumah Sakit Mata Cicendo Bandung $(n=60)$

\begin{tabular}{|c|c|c|c|c|}
\hline \multirow{3}{*}{ No } & \multirow{3}{*}{ Karakteristik } & \multicolumn{3}{|c|}{ Kelompok } \\
\hline & & RDNP Berat & RDP & Total \\
\hline & & n (\%) & n (\%) & n (\%) \\
\hline \multirow[t]{3}{*}{1} & Jenis Kelamin & & & \\
\hline & Laki-laki & $15(50)$ & $10(33,3)$ & $25(41,7)$ \\
\hline & Perempuan & $15(50)$ & $20(66,7)$ & $35(58,3)$ \\
\hline \multirow[t]{3}{*}{2} & Usia (Tahun) & & & \\
\hline & Usia 36-55 & $11(36,7)$ & $11(36,7)$ & $22(36,7)$ \\
\hline & Usia $>55$ & $19(63,3)$ & $19(63,3)$ & $38(63,3)$ \\
\hline \multirow[t]{4}{*}{3} & Pendidikan & & & \\
\hline & SMP & $8(26,7)$ & $10(33,3)$ & $18(30)$ \\
\hline & SMA & $14(46,7)$ & $14(46,7)$ & $28(46,7)$ \\
\hline & Pendidikan Tinggi & $8(26,7)$ & $6(20)$ & $14(23,3)$ \\
\hline \multirow[t]{3}{*}{4} & Status Pekerjaan & & & \\
\hline & Bekerja & $12(40)$ & $9(30)$ & $21(35)$ \\
\hline & $\begin{array}{l}\text { Tidak Bekerja/ } \\
\text { berhenti } \\
\text { pekerjaan/ }\end{array}$ & $18(60)$ & $21(70)$ & $39(65)$ \\
\hline \multirow[t]{4}{*}{5} & Durasi DM & & & \\
\hline & $<5$ Tahun & $1(3,3)$ & $1(3,3)$ & $2(3,3)$ \\
\hline & $5-10$ Tahun & $16(43,3)$ & $14(46,7)$ & $30(50)$ \\
\hline & $>10$ Tahun & $13(53,3)$ & $15(50)$ & $28(46,7)$ \\
\hline
\end{tabular}


Tabel 2 Distribusi Frekuensi Gambaran Kualitas Hidup Pasien Retinopati Diabetik Non-Proliferatif Berat dan Retinopati Diabetik Proliferatif di Poliklinik Vitreoretina Instalasi Rawat Jalan Pusat Mata Nasional Rumah Sakit Mata Cicendo Bandung

\begin{tabular}{lll}
\hline \multirow{2}{*}{ Kategori } & \multicolumn{2}{c}{ Kelompok } \\
\cline { 2 - 3 } & \multicolumn{1}{c}{ RDNP Berat } & RDP \\
\cline { 2 - 3 } & n (\%) & n (\%) \\
\hline Baik & $15(50)$ & $16(53,3)$ \\
Buruk & $15(50)$ & $14(46,7)$ \\
\hline Jumlah & $30(100)$ & $30(100)$ \\
\hline
\end{tabular}

Sumber : Data Primer 2019

Tabel 2 menunjukkan gambaran kualitas hidup pasien Retinopati Diabetik NonProliferatif Berat dan Retinopati Diabetik Proliferatif di Poliklinik Vitreoretina Instalasi Rawat Jalan Pusat Mata Nasional Rumah Sakit Mata Cicendo Bandung bahwa dari 30 pasien dengan RDNP Berat, separuhnya (50\%) memiliki kualitas hidup baik dan dari 30 pasien RDP, sebagian besar (53,3\%) memiliki kualitas hidup baik.

Kualitas hidup pasien Retinopati Diabetik Non-Proliferatif Berat dan Retinopati Diabetik Proliferatif di Poliklinik Vitreoretina Instalasi Rawat Jalan Pusat Mata Nasional Rumah Sakit Mata Cicendo Bandung bahwa dari 30 pasien dengan RDNP Berat, separuhnya (50\%) memiliki kualitas hidup baik dan dari 30 pasien RDP, sebagian besar $(53,3 \%)$ memiliki kualitas hidup baik.

Dampak RD pada kualitas hidup telah dievaluasi dalam beberapa penelitian menggunakan instrumen yang berbeda (Manaviat et al., 2016). Pada Penelitianpenelitian terbaru pasien RD menunjukkan penurunan terhadap HRQOL, namun dampak keparahan RD pada fungsi visual pasien belum terdokumentasikan dengan baik (Manaviat et al., 2016).

Tingkat keparahan yang lebih besar dari $\mathrm{RD}$ dikaitkan dengan kualitas hidup secara umum dan fungsi penglihatan yang rendah (Mazhar et al., 2011). pasien dengan RDNP berat mengalami penurunan kualitas hidup yang paling substansial dibandingkan dengan mereka yang memiliki RD yang kurang parah (Mazhar et al,. 2011).

Pasien RDP memiliki dampak signifikan pada kualitas hidup, terutama di bidang kemandirian, mobilitas, waktu luang, dan kegiatan perawatan diri.Pasien dengan RDP, menunjukkan skor HRQOL yang jauh lebih rendah untuk sebagian besar sub-skala NEI VFQ-25 dibandingkan dengan pasien tanpa RD (Mazhar et al., 2011). Mazhar et al. (2011) juga menemukan bahwa pasien dengan RD yang parah memiliki kualitas hidup dengan skor terendah pada sub skala kesulitan mengemudi.

Kamran et al. (2015) dalam penelitiannya menemukan bahwa kualitas hidup pada pasien dengan RDNP lebih baik daripada pasien dengan RDP. Pereira et al (2017) juga menyatakan bahwa kualitas hidup ternyata 
terkait dengan keparahan retinopati, skor terendah diperoleh dari mereka yang memiliki $\mathrm{RD}$ proliferatif. Ketika tingkat keparahan RD meningkat, kualitas hidup mengalami penurunan (Manaviat et al., 2016).

Tabel 3 Hasil Analisis Statistik dengan Chi square dengan koreksi Yates

\begin{tabular}{lllllll}
\hline & & \multicolumn{5}{c}{ Kualitas Hidup } \\
\cline { 3 - 6 } & & \multicolumn{3}{c}{ Baik } & \multicolumn{3}{c}{ Buruk } & Nilai \\
\cline { 3 - 6 } & $\mathbf{n}$ & $\mathbf{\%}$ & $\mathbf{n}$ & $\mathbf{\%}$ & $\mathbf{p}$ \\
\hline \multirow{2}{*}{ Jenis RD } & RDNP & 15 & 50,0 & 15 & 50,0 & 1,000 \\
& $\begin{array}{l}\text { Berat } \\
\text { RDP }\end{array}$ & 16 & 53,3 & 14 & 46,7 & \\
\hline Total & & 31 & 51,7 & 29 & 48,3 & \\
\hline
\end{tabular}

Tabel 3 memperlihatkan bahwa dari 30 responden dengan RDNP Berat separuhnya (50\%) memiliki kualitas hidup yang baik. Dan dari 30 responden dengan RDP sebagian besar $(53,3 \%)$ mempunyai kualitas hidup yang baik.

Hasil uji statistik dengan Chi square diperoleh nilai $p=1,000$, sehingga hipotesis penelitian yang diambil adalah $\mathrm{H}_{0}$ diterima. Hipotesis nol diterima mengandung makna bahwa tidak ada perbedaan kualitas hidup pada pasien RDNP Berat dan RDP di Poliklinik Vitreoretina Instalasi Rawat Jalan Pusat Mata Nasional Rumah Sakit Mata Cicendo Bandung.

Hasil dari penelitian ini menunjukkan bahwa tidak ada perbedaan kualitas hidup pada pasien RDNP Berat dan RDP di Poliklinik Vitreoretina Instalasi Rawat Jalan Pusat Mata Nasional Rumah Sakit Mata Cicendo Bandung. Hasil penelitian ini sejalan dengan yang dilakukan oleh Cetin et al. (2012) yang menyatakan bahwa tidak ada perbedaan yang signifikan antara total skor kualitas hidup dari pasien RDNP dan RDP $(p=0,42)$. Cetin et al.
(2012), dalam penelitiannya menyertakan faktor-faktor yang berhubungan dengan kualitas hidup pada pasien $\mathrm{RD}$, yaitu usia, jenis kelamin, pendidikan, durasi DM, ketajaman visual. Hasil penelitiannya menunjukkan bahwa skor kualitas hidup secara signifikan lebih tinggi pada pasien yang memiliki pendidikan yang lebih baik, memiliki durasi DM yang lebih pendek dan memiliki ketajaman visual yang lebih baik.

Penelitian yang dilakukan peneliti menghasilkan tidak ada perbedaan kualitas hidup pada pasien RDNP Berat dan RDP di Poliklinik Vitreoretina Instalasi Rawat Jalan Pusat Mata Nasional Rumah Sakit Mata Cicendo Bandung dapat terjadi akibat faktorfaktor yang mempengaruhi kualitas hidup pasien RD. Faktor-faktor yang mempengaruhi kualitas hidup pada pasien RD dapat dilihat pada karakteristik responden.

Karakteristik responden berdasarkan kategori usia, pada kelompok RDNP berat dan RDP memiliki rentang usia paling banyak yang sama $(63,3 \%)$ yaitu usia $>55$ tahun. Kategori usia responden yang sama dan paling banyak di kedua kelompok bisa mempengaruhi hasil pengukuran kualitas hidup, sehingga hasil yang diperoleh yaitu tidak ada perbedaan kualitas hidup pada pasien RDNP Berat dan RDP. Karmila (2014) menyebutkan bahwa faktor usia mempengaruhi kualitas hidup klien gangguan penglihatan dimana hal ini terkait dengan proses degeneratif. Sebagaimana yang dikatakan oleh Nickels et al. (2017) skor kualitas hidup yang lebih rendah diperoleh pada usia yang lebih tinggi. 
Karakteristik responden berdasarkan kategori pendidikan, pada kelompok RDNP berat dan RDP memiliki tingkat pendidikan paling banyak yang sama $(46,7 \%)$ yaitu pendidikan SMA. Moons et al. (2004) dalamNofitri (2009) mengatakan bahwa tingkat pendidikan merupakan salah satu faktor yang dapat mempengaruhi kualitas hidup secara subjektif. Kualitas hidup secara signifikan lebih tinggi pada pasien yang memiliki pendidikan yang lebih baik (Cetin et al., 2012). Pada penelitian ini, tingkat pendidikan yang sama banyak untuk tingkat pendidikan SMA, kemungkinan menjadi salah satu faktor tidak berbedanya kualitas hidup pada pasien RDNP Berat dan RDP.

Faktor lain yang dapat mempengaruhi kualitas hidup pada pasien RD yaitu ketajaman penglihatan. Peneliti tidak memasukkan faktor ini baik ke dalam kriteria inklusi maupun ke dalam karakteristik responden, karena untuk penelitian yang dilakukan saat ini, peneliti berfokus pada tingkat keparahan $\mathrm{RD}$, terutama RDNP berat dan RDP. Sehingga ketajaman penglihatan antara pasien RDNP berat dan RDP tidak bisa dilihat perbedaannya dari karakteristik responden. Skalicky \& Goldberg (2013), dalam hasil penelitiannya menyatakan bahwa penglihatan yang terbatas akan menyebabkan penurunan kualitas hidup. RD dengan ketajaman visual yang baik tidak secara signifikan mempengaruhi HRQoL namun skor kualitas hidup cenderung lebih rendah ketika RD telah mengakibatkan penurunan ketajaman penglihatan (Hannula, 2015).
Faktor ketajaman penglihatan yang tidak disertakan dalam penelitian ini menjadi salah satu keterbatasan peneliti. sehingga keterbatasan penelitian ini bisa dijadikan perbaikan untuk penelitian berikutnya, baik bagi peneliti sendiri maupun bagi calon peneliti lainnya.

\section{SIMPULAN DAN SARAN}

\section{Simpulan}

Hasil penelitian dan pembahasan tentang "Perbedaan Kualitas Hidup Pada Pasien Retinopati Diabetik Non-Proliferatif Berat dan Retinopati Diabetik Proliferatif Di Pusat Mata Nasional Rumah Sakit Mata Cicendo Bandung" dapat ditarik kesimpulan sebagai berikut:

1. Pasien RDNP Berat dan RDP di Poliklinik Vitreoretina Instalasi Rawat Jalan Pusat Mata Nasional Rumah Sakit Mata Cicendo Bandungmemiliki karakteristik sebagai berikut: sebagian besar $(58,3 \%)$ berjenis kelamin perempuan; sebagian besar $(63,3 \%)$ termasuk kategori usia $>55$ tahun; hampir separuhnya $(46,7 \%)$ memiliki tingkat pendidikan SMA; sebagian besar $(65 \%)$ tidak bekerja dan separuhnya $(50 \%)$ memiliki durasi DM 5- 10 tahun.

2. Kualitas hidup pasien Retinopati Diabetik Non-Proliferatif Berat dan Retinopati Diabetik Proliferatif di Poliklinik Vitreoretina Instalasi Rawat Jalan Pusat Mata Nasional Rumah Sakit Mata Cicendo Bandung menunjukkan bahwa dari 30 pasien dengan RDNP Berat, separuhnya (50\%) memiliki kualitas hidup baik dan 
dari 30 pasien RDP, sebagian besar $(53,3 \%)$ memiliki kualitas hidup baik.

3. Tidak ada perbedaan kualitas hidup pada pasien retinopati diabetik non-proliferatif berat dan retinopati diabetik proliferatif di Poliklinik Vitreoretina Instalasi Rawat Jalan Pusat Mata Nasional Rumah Sakit Mata Cicendo Bandung $(p=1,000)$.

\section{Saran}

1. Bagi Pusat Mata Nasional (PMN) Rumah Sakit Mata Cicendo

PMN Rumah Sakit Mata Cicendo diharapkan memiliki kebijakan mengenai pemberian asuhan kepada pasien RD, tidak hanya difokuskan pada tingkat keparahan penyakit, tetapi kepada faktor-faktor lain yang bisa mempengaruhi kualitas hidup pasien RD, diantaranya yaitu durasi DM, usia, dan tajam penglihatan.

2. Bagi Perawat

Perawat diharapkan dapat memberikan edukasi dan dorongan kepada pasienRDNP berat dan RDP untuk melakukan kontrol teratur, baik kontrol mengenai gangguan penglihatannya, maupun kontrol penyakit diabetesnya, sehingga pasien terhindar dari kondisi penurunan kualitas hidup yang lebih buruk.

3. Bagi Peneliti Selanjutnya

Untuk penelitian selanjutnya disarankan untuk menambahkan kriteria inklusi dan eksklusi subjek penelitian berdasarkan faktor-faktor yang dapat mempengaruhi kualitas hidup pada pasien RD, yaitu usia; jenis kelamin; tingkat keparahan RD; pendidikan; pekerjaan; durasi DM; dan tajam penglihatan.

\section{DAFTAR PUSTAKA}

Alinia, C., Mohammadi, S. F., Lashay, A., dan Rashidian, A. Impact of diabetic retinopathy on health-related quality of life in Iranian diabetics. Iranian Journal Of Public Health. 2017;46(1):55-65

Alcubierre, N., Rubiat, E., Traveset, A., Martinez-Alonzo, M., Hernandez, M., Jurjo, C., et al. A prospective crosssectional study on quality of life and treatment satisfaction in type 2 diabetic patients with retinopathy without other major late diabetic complications. Health Qual Life Outcomes. 2014;12(1):1-7

American Diabetes Association. Classification and diagnosis of diabetes: Standards of Medical Care Diabetes-2019. Diabetes Care. 2019;42 Suppl 1:S13-S28

American Academy of Ophthalmology. Preferred Practice PatternGuidelines. Diabetic Retinopathy [internet]. San Francisco: American Academy of Ophthalmology; 2016 [Dikutip 08 April 2018]. Tersedia dari: https://www.aao.org/ppp

Bhavsar, A.R. Diabetic Retinopathy: Practice Essentials, Pathophysiology, Etiology [internet] 2017 Apr 19 [Dikutip 08 April 2018]. Tersedia dari: https://emedicine.medscape.com/article/1 $\underline{\text { 225122-overview }}$

Billah, M., Rahim, M.A., Rahman, A., Mitra, P., Chowdhury, T.F., Hossan, E., etal. Pattern and risk factors of diabetic retinopathy among type 2 diabetic patients: experience in a tertiary care hospital. J Medicine. 2016; 17(1): 17-20

Brose, L.S., Bradley, C. Psychometric development of the individualizedretinopathy-dependent quality of life questionnaire(RetDQoL). Value In Health. 2010;13(1):119-127 
Boyd, S., Girach, A., dan Pelayes, D., penyunting. 2010. Diagnosis and Treatment of Diabetic Retinopathy. Panama: Jaypee Highlights Medical Publisher

Cavan, D., Makaroff, L., Fernandes D.R.J., Sylvanowicz, M., Ackland, P., Conlon, et al. The diabetic retinopathy barometer study: global perspectives on access to and experiences of diabetic retinopathy screening and treatment. Diabetes research and clinical practice. 2017;129:16-24

Cetin, E.N., Bulgib, Y., Zencir, M., Avunduk, A.M., Yaylalp, V., Yildirim, C. Vision related quality of life in patients with diabetic retinopathy. Ret-Vit. 2012;20:213-21

Dahlan, S. 2014. Statistik untuk Kedokteran dan Kesehatan: Deskriptif, Bivariat, dan Multivariat. Edisi 6. Jakarta: Epidemiologi Indonesia

Davidov, E., Breitscheidel, L., Clouth, J., Reips, M., dan Happich, M. Diabetic retinopathy and health-related quality of life. Graefe's Archive for Clinical and Experimental Ophthalmology. 2009;247:267-272

Dharma, K.K. 2017. Metodologi Penelitian Keperawatan. Edisi Revisi Tahun 2015. Jakarta: CV Trans Info Media

Farhana, H.R. Pengembangan Dan Penggunaan Asesmen Alternatif Elektronik (Aae) Dalam Menilai Sikap Ilmiah Dan Penguasaan Konsep Siswa Pada Konsep Sistem Pertahanan Tubuh [internet]. Bandung: Universitas Pendidikan Indonesia, 2014 [dikutip 19 Agustus 2019]. Tersedia dari: http://repository.upi.edu/

Fenwick, E. K., Pesudovs, K., Khadka, J., Dirani, M., Rees, G., Wong, T.Y., et al. The impact of diabetic retinopathy on quality of life: qualitative findings from an item bank development project.Quality of Life Research. 2012a;21:1771-1782
Fenwick, E., Rees, G., Pesudovs, K., Dirani, M., Kawasaki, R., Wong, T. Y., et al. Social and emotional impact of diabetic retinopathy: a review. Clinical \& experimental ophthalmology. $2012 b ; 40: 27-38$

Gabrielian, A., Hariprasad, S.M., Jager. R.D., Green, J.L., dan Mieler, W.F. The utility of visual function questionnaire in the assessment of the impact of diabetic retinopathy on vision-related quality of life. Eye. 2010;24:29-35

Gudla, S., Tenneti, D., Pande, M. dan Tipparaju, S.M. Diabetic Retinopathy: pathogenesis, treatment, and complications. Dalam: Patel J., Sutariya V., Kanwar J., Pathak Y, penyunting. Drug Delivery for the Retina and Posterior Segment Disease. Cham: Springer; 2018. h.83-94

Goyal, M., Kamboj, P., Behgal, J., Rathee, S., Lather, R. Risk factors of diabetic retinopathy in patients with type 2 diabetes mellitus. Diabetes Manag.2017;7(6):408-411

Hannula, V. 2015. The prevalence of diabetic retinopathy and its effect on social wellbeing and health related quality of life in children and young adults with type 1 diabetes [internet]. University of Oulu, 2015 [dikutip 25 November 2018]. Tersedia dari: http://jultika.oulu.fi/Record/isbn978-952$\underline{62-0964-7}$

Harding, J. L., Pavkov, M. E., Magliano, D. J., Shaw, J. E., dan Gregg, E. W. Global trends in diabetes complications: a review of current evidence. Diabetologia. 2019;62(1):3-16

He, B., Wei, L., Gu, Y.J., Han J.F., Li, M., Liu Y.X., et al. Factors associated with diabetic retinopathy in chinese patients with type 2 diabetes mellitus [internet]. International Journal of Endocrinology; vol. 2012 [dikutip 06 Februari 2019]. Tersedia dari: https://doi.org/10.1155/2012/157940 
Hidayat, A.A.A. 2011. Metode Penelitian Keperawatan dan Teknik Analisis Data. Jakarta: Salemba Medika

Ilyas, S. 2010. Sari Ilmu Penyakit Mata. Edisi 3. Jakarta : Balai Penerbit FKUI

International Council of Ophthalmology. ICO Guidelines for Diabetic Eye Care [internet]. [Diunduh 25 Nopember 2018]. Tersedia dari: https://www.icoph.org/enhancing_eyecare /diabetic eyecare.html

International Diabetes Federation. IDF Diabetes Atlas, 8th edn [internet]. Brussels:

International Diabetes Federation; 2017 [Diunduh 26 Nopember 2018]. Tersedia dari: https://www.idf.org/elibrary/epidemiology-research/diabetesatlas/134-idf-diabetes-atlas-8thedition.html

International Diabetes Federation and The Fred Hollows Foundation. Diabetes eye health: A guide for health care professionals [internet]. Brussels: International Diabetes Federation; 2015 [Diunduh 08 April 2018]. Tersedia dari: https://www.idf.org/ouractivities/advocacy-awareness/resourcesand-tools/76:diabetes-eye-health-a-guidefor-health-professionals-en.html

International Federation on Ageing, International Agency for the Prevention of Blindness, International Diabetes Federation. The Diabetic Retinopathy Barometer Report: Global Findings [internet] 2016 [Diunduh 27 Desember 2018]. Tersedia dari: https://www.idf.org/elibrary/epidemiology-research/diabetesatlas/92-diabetic-retinopathybarometer.html

Kamran, J.S., Jafroudi, S., Leili, E.K.N., Chafjiri, A.S., Paryad, E. Quality of Life in Patients with Diabetic Retinopathy. Journal of Holistic Nursing and Midwifery. 2017;27(1):69-77
Karmila, M. 2014. Kualitas Hidup Penderita Glaukoma Di RSUP. H. Adam Malik Dan RSUD Pirngadi Medan Tahun 2012. Medan: Departemen Ilmu Kesehatan Mata Fakultas Kedokteran Universitas Sumatera Utara

Kemenkes RI. 2013. Laporan Hasil Riset Kesehatan Dasar (Riskesdas) Indonesia Tahun 2013. Jakarta : Badan Penelitian dan Pengembangan Kesehatan Kemenkes RI

Khandekar, R., Lawatii, J.,A., Mohammed, A.,J., dan Raisi, L. Retinopati diabetik in Oman: a hospital based study. British Medical Journal. 2011;87:1061-1064

Klein, R., Lee, K.E., Gangnon, R.E., Klein, B.E.K. The 25-year incidence of visual impairment in type 1 diabetes mellitus the wisconsin epidemiologic study of diabetic retinopathy.Ophthalmology. 2010;17(1):63-70

Lee, R., Wong, T. Y., dan Sabanayagam, C. Epidemiology of diabetic retinopathy, diabetic macular edema and related vision loss. Eye and vision. 2015; 2:17

Maa, A.Y., dan Sullivan, B.R. Relationship of $\mathrm{HbAlc}$ with the presence and severity of retinopathy upon initial screening of type II diabetes mellitus. American Journal of Ophthalmology. 2009;114:456-457

Manaviat, M.R., Namiranian, N., Kermanian, M., Ardakani, E.D. Relationship between diabetic retinopathy and its severity and health-related quality of life using national eye institute visual function questionnaire. Acta HealthMedica. 2016;1:29-33

Mangione, C.M. NEI-VFQ Scoring Algorithm[internet] 2000 Agust [Diunduh 24 Juli 2018]. Tersedia dari: https://nei.nih.gov/catalog/visualfunction-questionnaire-25

Mangione, C. M., Lee, P. P., Gutierrez, P. R., Spritzer, K., Berry, S., dan Hays, R. D. Development of the 25-list-item National Eye Institute Visual Function 
Questionnaire. Arch of ophthalmol. 2001;119:1050-1058

Marendra, R., dan Iskandar, E. 2017. Faktor Risiko Sight Threatening Diabetic Retinopathy(STDR) Penderita Retinopati Diabetika Di Pusat Mata Nasional RS Mata Cicendo. Bandung : Departemen Ilmu Kesehatan Mata Fakultas Kedokteran Universitas Padjadjaran

Mazhar, K., Varma, R., Choudhury, F., McKean-Cowdin, R., Shtir, C. J., Azen, S. P., \& Los Angeles Latino Eye Study Group. Severity of diabetic retinopathy and health-related quality of life: the Los Angeles latino eye study. Ophthalmology.2011;118(4):649655.

Milne, A., Johnson, J.A., Tennant, M., Rudnisky, C., dan Dryden, D.M. Measuring Health-Related Quality of Life for Patients with Diabetic Retinopathy [internet]. Rockville (MD): Agency for Healthcare Research and Quality (US); 2012 Apr 23 [Dikutip 01 Maret 2019]. Tersedia dari: https://www.ncbi.nlm.nih.gov/books/NBK $\underline{248340 /}$

Nickels, S., Schuster, A.K., Singer, S., Wild, P.S., Laubert-Reh, D., Schulz, A., et al. The National Eye Institute 25-Item Visual Function Questionnaire (NEI VFQ-25)reference data from the German population-based Gutenberg Health Study (GHS). Health and Quality of Life Outcomes. 2017;15:156

National Institute for Diabetes and Digestive and Kidney Diseases. Diabetes [internet] [Dikutip 04 Mei 2019]. Tersedia dari: https://www.niddk.nih.gov/healthinformation/diabetes

Nofitri, N.,F.,M. 2009. Gambaran Kualitas Hidup Penduduk Dewasa pada Lima Wilayah di Jakarta. Fakultas Psikologi Universitas Indonesia.

Notoatmodjo, S. 2014. Metodologi Penelitian Kesehatan. Edisi Revisi. Jakarta : Rineka Cipta
Nursalam. 2013. Metodologi Penelitian Ilmu Keperawatan: Pendekatan Praktis. Edisi 3. Jakarta : Salemba Medika

Ozawa, G.Y., Jr., M.A.B., Adams, A.J. Malefemale differences in diabetic retinopathy?.Current Eye Research. 2015; 40(2): 234-246

Pan, C., Wang, S., Qian, D., Xu, C., Song, E. Prevalence, Awareness, and Risk Factors of Diabetic Retinopathy among Adults with Known Type 2 Diabetes Mellitus in an Urban Community in China [internet]. Ophthalmic Epidemiology; 2017 Feb 25 [dikutip 18 Nopember 2018]. Tersedia dari:

https://doi.org/10.1080/09286586.2016.12 $\underline{64612}$

Pandelaki K. 2014. Retinopati Diabetik. Dalam: W. Sudoyo, B. Setiyohadi, I. Alwi, M. Simadibrata K, dan S. Setiati. Buku ajar ilmu peyakit dalam. Edisi ke-5. Jakarta: Internal Publishing

Pereira, D.M., Shah, A., D'Souza, M., Simon, P., George, T., D'Souza, N., et al. Quality of life in people with diabetic retinopathy: Indian study. Journal of Clinical and Diagnostic Research. 2017;11(4): NC01NC06

PERKENI. 2015. Konsensus Pengelolaan Dan Pencegahan Diabetes Melitus Tipe 2 Di Indonesia 2015. PB PERKENI

Plummer, M., dan Molzahn, A.E. Quality of life in contemporary nursing theory. Nursing Science Quarterly. 2009;22(2):134-140

Priya, P.V., Srinivasarao, D., dan Sharma, D. Diabetic retinopathy-can lead to complete blindness. IJSIT. 2013;2(4):254-265

Punthakee, Z., Goldenberg, R. and Katz, P. Definition, classification and diagnosis of diabetes, prediabetes and metabolic syndrome. Canadian journal of diabetes. 2018;42 Suppl 1:S10-S11 
Remington, L.A. 2012. Clinical Anatomy And Physiology Of The Visual System. Third Edition. Missouri : Elsevier ButterworthHeinemann

Sari, N. M. S. A., dan Saraswati, M. R. Prevalensi retinopati diabetika pada pasien diabetes melitus tipe 2 di poliklinik penyakit dalam RSUP Sanglah Denpasar. e-Jurnal Medika Udayana. 2013;2(6):1090-1099

Shrestha, G. S., dan Kaiti, R. Visual Functions And Disability In Diabetic Retinopathy Patients. Journal of optometry. 2013;7(1):37-43

Skalicky, S.,Goldberg, I. Quality of life in glaucoma patients. US Ophthalmic Review. 2013;6(1):6-9

Soewondo P et al. The Diabcare Asia 2008 study-outcomes on control and complications of type 2 diabetic patients in Indonesia. the Diabcare Asia 2008 study. The DiabCare Asia 2008 study. 2010;19(4):235-244

Stewart, M.W. 2017. Diabetic Retinopathy: Current Pharmacologic Treatment And Emerging Strategies. Singapore : Springer Nature

Sugiyono. 2016. Metodologi Penelitian Kuantitatif, Kualitatif, dan Kombinasi (Mixed Methods). Bandung : Alfabeta

Sugiyono. 2018. Metode Penelitian Kuantitatif. Bandung : Alfabeta

The Royal College of Ophthalmologists. Diabetic Retinopathy Guidelines [internet] 2012 Des [Diunduh 24 Juli 2018]. Tersedia dari: https://www.rcophth.ac.uk/standardspublications-research/commissioning-inophthalmology/diabetic-retinopathy/

Triana, D. 2017. Hubungan Antara Dukungan Keluarga Dengan Kualitas Hidup Klien Yang Mengalami Retinopati Diabetik Di Poli Retina Pusat Mata Nasional Rumah Sakit Mata Cicendo Bandung. Bandung: STIKes Bhakti Kencana
Wahyuni, Y., Nursiswati, N., dan Anna, A. Kualitas Hidup Berdasarkan Karekteristik Pasien Diabetes Melitus Tipe 2. Jurnal Keperawatan Padjadjaran. 2014; 2(1)

Wang, W. dan Lo, A. Diabetic retinopathy: pathophysiology and treatments. International journal of molecular sciences. 2018;19(6):1816

World Health Organization. WHOQOL: Measuring Quality of Life [internet]. 2014 [Dikutip 17 November 2018]. Tersedia dari: https://www.who.int/healthinfo/survey/wh oqol-qualityoflife/en/

Yau, J.W.Y., Rogers, S.L., Kawasaki, R., Lamoureux, E.L., Kowalski, J.W., Bek, T., Chen, S.J., et al. Global prevalence and major risk factors of diabetic retinopathy. Diabetes Care. 2012;35:556564

Yousefi, P., Rasekhi, S., Heshmati, H. Quality of life in medical sciences. International Journal of Medical Research \& Health Sciences. 2016;5(S):43-46

Zhao, C., Wang, W., Xu, D., Li, H., Li, M., dan Wang, F. Insulin and risk of diabetic retinopathy in patients with type 2 diabetes mellitus: data from a metaanalysis of seven cohort studies. Diagnostic pathology. 2014;9:130

Zhou, Y., Wang, C., Shi, K., dan Yin, X. Relationship between dyslipidemia and diabetic retinopathy: a systematic review and meta-analysis. Medicine. 2018;97:36 